Macarena de la Vega
Emil Kaufmann's Von Ledoux bis Le Corbusier: Ursprung und Entwicklung der autonomen

Architektur, 1933

(Tournikiotis [2014])
Macarena de la Vega. Architect. Master Degree UPM. PhD student University of Canberra.

\section{Reconsidering Emil Kaufmann's Von Ledoux bis Le Corbusier}

El objetivo de este ensayo es re-abrir y re-leer Von Ledoux bis Le Corbusier de Emil Kaufmann. A pesar de que Panayotis Tournikiotis y Anthony Vidler lo incluyeran en sus respectivos discursos sobre la historiografia de la arquitectura moderna, se propone reconsiderar a su autor como un historiador pionero de la Ilustración. Tres ideas: el único protagonista del libro es Claude-Nicolas Ledoux; la arquitectura en torno a 1800 necesitaba una reevaluación; y la obra de Kaufmann se enmarca en un tiempo de búsqueda de una nueva ciencia del arte y una nueva historia de la arquitectura. Kaufmann es una figura de transición entre una generación previa de historiadores del arte que establecieron conceptos y principios fundamentales, $y$ otros de su misma generación que se embarcaron en la tarea de considerar la arquitectura moderna como objeto de una investigación histórica.

Can Emil Kaufmann's Von Ledoux bis Le Corbusier be considered a history of modern architecture? Contrary to what certain theorists have proposed in their works, this research aims to re-open and re-read Von Ledoux bis Le Corbusier: Ursprung und Entwicklung der auntonomen Architektur in order to reconsider Kaufmann as a pioneer historian of the Age of Reason, rather than a historian of modern architecture.

On the one hand, Von Ledoux bis Le Corbusier is discussed in two studies: first, in Panayotis Tournikiotis' The Historiography of Modern Architecture published in 1999; and second, in Anthony Vidler's Histories of the Immediate Present published in 2008. According to Tournikiotis, Emil Kaufmann's discourse is "plainly operative", functions as a "manifesto" and "establish[es] the modern movement and reveal[s] it as victorious" (Tournikiotis 1999: 21, 22, 26). Tournikiotis' arguments will be confronted exclusively with the book's content. Focusing on the concept of autonomy allows Vidler not to refer to this book as a history of modern architecture. However, Kaufmann appears in a list together with Colin Rowe, Reyner Banham and Manfredo Tafuri, so it can be understood that Vidler, too, included him in his particular historiography of modern architecture.

On the other hand, there are other studies that have not included Kaufmann's book. First, Maria Luisa Scalvini and Maria Grazia Sandri in L'immagine storiografica dell'architettura contemporanea da Platz a Giedion briefly mention Kaufmann and his book in a footnote from the chapter about Henry-Russell Hitchcock. Scalvini emphasizes "Kaufmann's interest for French revolutionary architecture, an interest

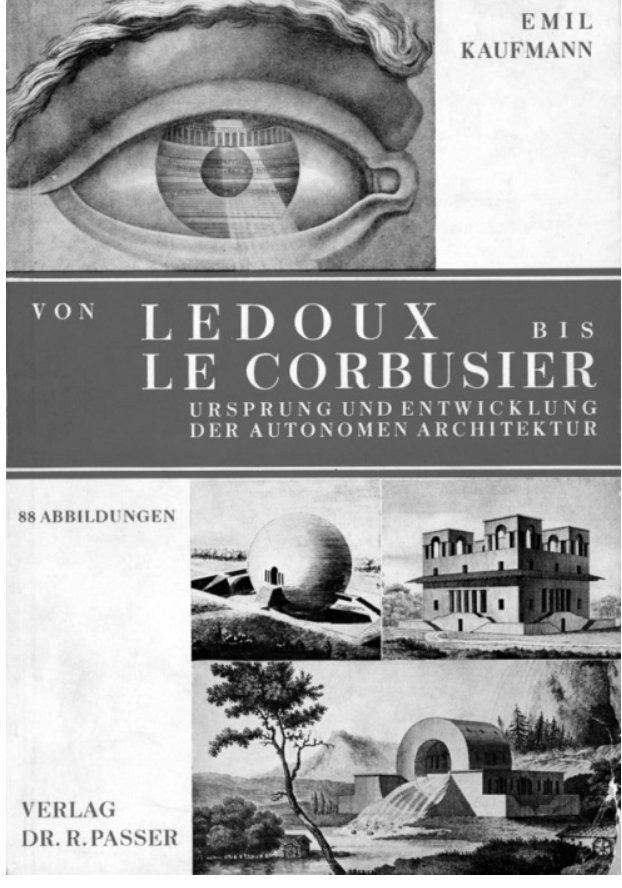

shown in the majority of his scholarly production" (Scalvini and Sandri 1984: 79). Second, in a more recent investigation published in 2011 Gevork Hartoonian's The mental life of the architectural historian: re-opening the early historiography of modern architecture, Kaufmann is not the object of any chapter. Hartoonian makes small references to the historian -always linked with the concept of autonomywhich appear in three chapters dedicated to three historians: Nikolaus Pevsner, Henry-Russell Hitchcock and Sigfried Giedion; as well as in the final chapter entitled "Adieu Zeitgeist!"

This ambiguity in the consideration of Emil Kaufmann by different theorists, which contrasts with the lack of doubt in the cases of Pevsner or Giedion, reveals the need for a thorough re-evaluation. 


\section{From Ledoux to Kaufmann}

Von Ledoux bis Le Corbusier: Ursprung und Entwicklung der autonomen Architektur is the only alleged history of modern architecture written in German. It was published in 1933 in Viena, at a time when "the true specificity of Kaufmann's analysis is defined", according to Gilbert Erouart (1980: 10). In the preface, Kaufmann states two main objectives: on the one hand, to present Ledoux's work and thinking "as more than just a biography, something else as a mosaic of an artist's life"; and, on the other, to attempt "a reinterpretation of the architectural development of the nineteenth and twentieth centuries" (Kaufmann 1982: 7).

The beginning of the twentieth century was a time when the history of architecture was being written by art historians; not only the history of modern architecture, but also of Renaissance, Baroque and Neoclassical architecture. The nineteenth century was still in need of a conceptualization. To truly understand Kaufmann's work, it has to be considered in the context of the historiography of art, in the context of the structuralist analysis theorized by "The New Viennese School". Works by Heinrich Wölfflin and Paul Frankl could be considered relevant to exemplify the situation of the history of art at this time. Significant differences are to be found in the way both Wölfflin and Frankl present the architecture of the years around 1800 .

First, in 1914 Frankl's Die Entwicklungsphasen der neueren Baukunst appeared. Frankl proposes four analytical categories to examine four development phases: Renai-ssance, Baroque, Rococo and Neoclassicism. According to Frankl, nothing but continuity exists between each of these phases, and Neoclassicism returns to Classicism and the Renaissance, describing a "circle uniform and closed" (Frankl 1981: 254). Second, just one year later, in 1915 Wölfflin's Kunstgeschichtliche Grund- begriffe: das Problem der Stilentwicklung in der neueren Kunst was published. Wölfflin's discussion of Renaissance and Baroque architecture contrasts a series of concepts. At the end of every chapter, he mentions a "new style" at the end of the eighteenth century, characterized as "unusual", as a "process of profound regeneration" (Wölfflin 1924: 337). According to Wölfflin's analysis, it seems like a new start but not a return to the starting point. Where Frankl sees a circle, Wölfflin understands that the spiral is the geometrical figure that best exemplifies the process of rupture and restart in the development of art. In the midst of such a debate, Kaufmann agrees with Wölfflin in observing an interruption when he tries to define Neoclassicism in Von Ledoux bis Le Corbusier.

"Neoclassicism was a last attempt in that direction; it was not a reanimation, but, fair and completely, the end of classical art. This is how we see the second half of the eighteenth century in the universal history and the history of literature and art: first, new ideas; then, a profound restlessness, the search for new paths, passionate mistakes and failures; (...) only rarely the realization of these new ideas, in the Civil Code or, more clearly, in Ledoux's architectural legacy". (1982: 65)

Kaufmann understands architecture around 1800 as a body of work in need of reevaluation. Why? In his opinion, the rupture or crisis in European thinking at that time was considered to have had impact exclusively on philosophical, literary and social spheres. How is it possible that in the arts one would only perceive a sterile Neoclassicism? Kaufmann criticized previous historians for not going beyond the pretended antique epidermis. "Excessive attention should not be paid to merely superficial phenomena. On the contrary, processes which take place under the surface are decisive" (1982: 63).

This type of analysis, which looks beyond appearances and focuses on buildings' internal structure, is what Kaufmann presents of Ledoux's work. Ledoux was at that time a forgotten architect, and, in Kaufmann's opinion, rediscovering and considering his work was "enough" to exemplify architecture in the time of French Revolution. His work was a result of the times, a true reflection, but it was not appreciated then, "his own time did not understand him" (1982: 27).

How does Kaufmann present this artist in Von Ledoux bis Le Corbusier? The main idea is transition: Ledoux lives and works between two époques, understands both of them and practices both resultant architectures. Kaufmann's discourse is mainly a description and classification of Ledoux's work and shows the development from a more heteronomous work to buildings that are examples of architectural autonomy; it shows a structural transformation. The idea of Ledoux as a transitional artist appears throughout the book, and by the end, Kaufmann introduces an important nuance: Ledoux as a "limit artist", capable 
Pages from De Ledoux a Le Corbusier (1982) that illustrate the Spanish edition of

Tournikiotis' Historiography. (Tournikiotis [2014])

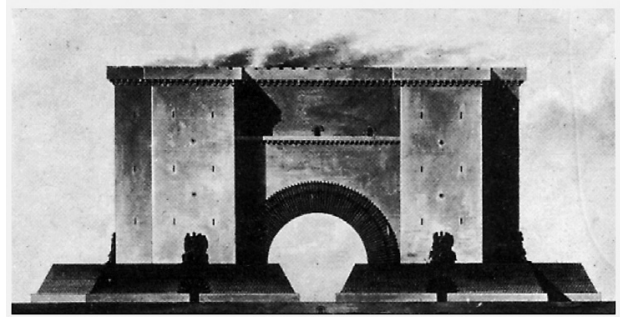

Fig. 26. E. L. Boullée, Proyecto de una puerta de acceso a la ciudad

(fig. 28) de 1772. (El «Templo de Terpsícore», sito en la Chaussée d'Antin y a cuya decoración interior contribuyeron David y Fragonard, fue un regalo del Mariscal de Soubise.) Mientras que el Barroco era la expresion de sentimientos desatados e ilustraba la pasion por la potencia de las masas, por la fuerza de las formas -de ahi su por la potencia de las masas, por la fuerza de las formas -de ahi su
predilección por lo egipcio, que no cristalizó tan sólo a causa de la campaña napoleónica- $y$, en fin, por el tratamiento de los materiales. La ciclópea prominencia de los edificios para las Salinas, la imponente disposición del Palacio de Justicia de Aix (fig. 3), la gravedad de la

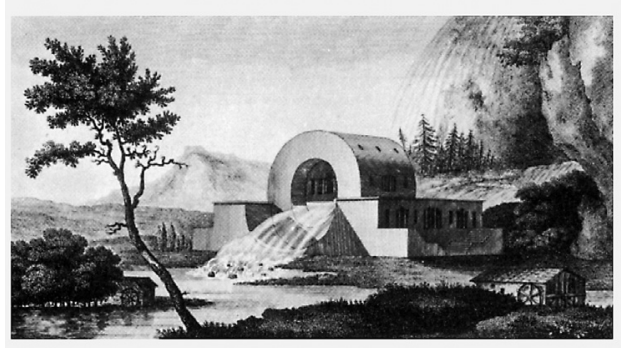

Fig. 27. C. N. Ledoux, Vivienda para los guardas del rio Loue

of working in both the old and the new manner. Kaufmann uses, among others, the metaphor of a river and Ledoux is one of the first to cross from one side to the other, feeling comfortable on both sides, he lives in the limit and walks constantly the distance from one side to the other. Despite his own chronological discourse, Kaufmann claims that to establish a chronological evolution is a useless task and that Ledoux's relevance comes mainly from his knowledge of the old. Paradoxically, it is precisely that knowledge of old forms that makes him attempt to transform them, to design them in a different manner. Kaufmann's "transitional figure" differs not much from Wöfflin's "Magna individuality": a debt admitted by Kaufmann himself in an essay in 1943. According to Wölfflin, "when new possibilities are fully incorporated in its last style, it can be inferred that a new sensitivity is in need of a new style. However, those new style possibilities were the result of leaving behind some of the old possibilities" (1924: 329).

At the end of both their books, Wölfflin and Frankl admit that their analytical categories cannot be used to examine a new style. Only a few years after, Kaufmann considers that if every time is characterized by its own artistic will and "every time has its own basic ideas about the disposition and interrelation of elements" (1943: $17)$ then it seems correct that "every time
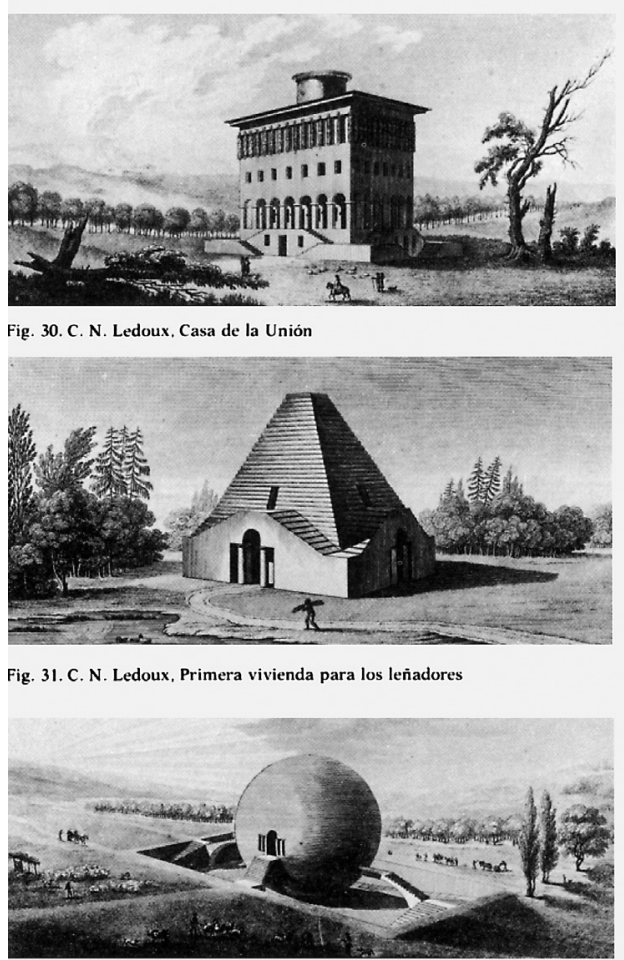

Fig. 32. C. N. Ledoux, Albergue para los guardias rurales

requires specific categories of treatment" (1946: 283). The idea that a new time requires new categories was part of the debate, not only in the first decade of the twentieth century, but also during the 1930s and the 1940s. During that time, the theorist John Coolidge was trying to establish the "Preliminary steps towards "The New History of Architecture"' (1943), and Paul Zucker, was finding "The Paradox of Architectural Theories at the beginning of the Modern Movement" (1951). In Kaufmann's case, Gilbert Erouart and Georges Teyssot have amply discussed these new categories and have clearly explained the difference between "Einheit" and "Vielheit", "heteronomy" and "autonomy", "Barock-Verband" and "Pavillon-system". Also, concepts like "Baroque's unity disintegration" or "isolation principle", once again inherited from Wölfflin's thinking. This is reason enough not to focus on the definition of such categories and to try and go beyond them, towards a new attempt of interpretation.

A careful reading of Von Ledoux bis Le Corbusier shows that Kaufmann not only uses Ledoux's work to define two different systems, but he also makes a great effort to clarify the transition between both of them. The formal features of the heteronomous and the autonomous architecture are easily detected, but the task of every engaged historian, the true novelty Kaufmann offers in this book, is the defi- 
nition of this process through a series of phases. Only Vidler -and only when he takes into account the essay "Die Stadt des Architekten Ledoux" (1933) and not the book- discusses the idea of "an organic and slow process of internalization and cognition on the part of the architect" which results in the "discovery" (Erkenntnis) of autonomy, "through a number of stages represented by detailed analyses of Ledoux's designs in roughly chronological order" (2008: 24).

The stages, which Vidler detects in Kaufmann's essay on the Saltworks of Chaux, can be outlined in Von Ledoux bis Le Corbusier, too. First, the transitional works characterized as an "architecture of isolation" and formed by "functionally defined and formally expressed units" (Vidler 2008: 24): transitional works in which Kaufmann detects "a contrast between the interior and exterior" (Kaufmann 1982: 42). Second, Kaufmann discusses five simultaneous tendencies in architecture around 1800, which the visionary architecture of the Revolution embodied: Romanticism, architecture parlante, formal experiments and two others in which the intention was to create effects or an extraordinary impression, according to the author. Kaufmann uses Ledoux's work to describe these tendencies and the process continues with the "symbolic system" embodied in buildings like the

Pages from De Ledoux a Le Corbusier (1982) that illustrate the Spanish edition of Tournikiotis' Historiography. (Tournikiotis [2014])

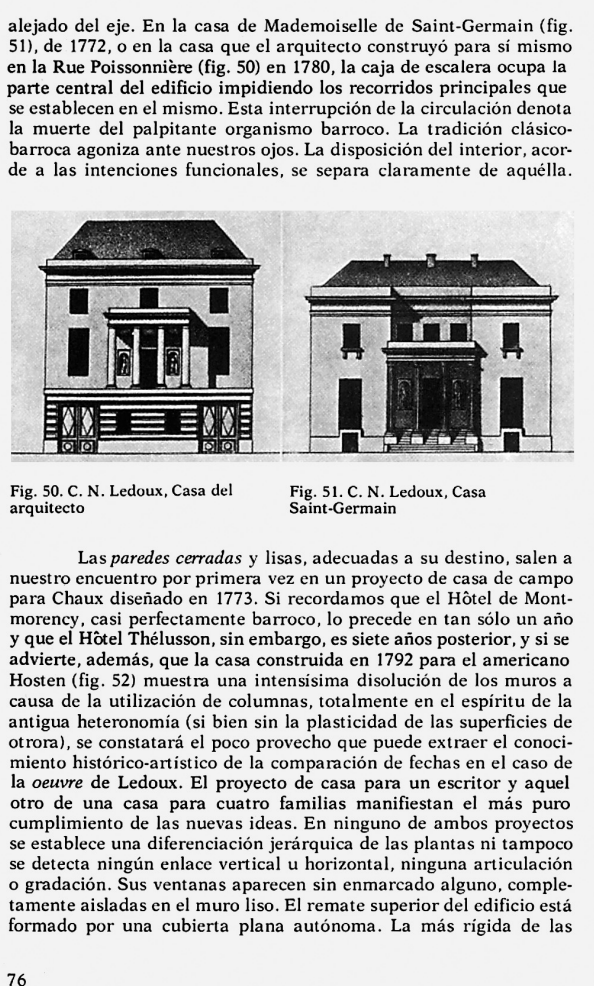

alejado del eje. En la casa de Mademoiselle de Saint-Germain (fig. in de 1772,0 en la casa que el arquitecto construyó para sí mismo parte central del edificio impidiendo los recorridos principales que la muerte del palpitante organismo barroco. La tradición clásico. barroca agoniza ante nuestros ojos. La disposición del interior, acode a las intenciones funcionales, se separa claramente de aquélla.

$\begin{array}{ll}\begin{array}{l}\text { Fig. 50. C. N. Ledoux, Casa del } \\ \text { arquitecto }\end{array} & \begin{array}{l}\text { Fig. 51.C. N. Ledoux, Casa } \\ \text { Saint-Germain }\end{array}\end{array}$

Las paredes cerradas $\mathrm{y}$ lisas, adecuadas a su destino, salen a

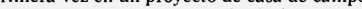
para Chaux distenado en 1773 . Si recordamos que el Hotel de Monmorency, casi perfectamente barroco, lo precede en tan sólo un año advierte, además, que la casa construida en 1792 para el americano Hosten (fig. 52) muestra una intensisima disolución de los muros antigua heteronomia (si bien sin la plasticidad de las superficies de otrora), se constatará el poco provecho que puede extraer el conocimiento historico-artistico de la comparacion de fechas en el caso de otro de una casa. cumplimiento de las nuevas ideas. En ninguno de ambos proyectos se detecta ningún enlace vertical u horizontal, ninguna articulación o gradacion. Sus ventanas aparecen sin enmarcado alguno, compleles del siglo XVIII. La silueta permite destacar netamente el objeto representado del ambiente en que se encuentra, la más estricta similarion a lo esencial, la supresion de lo secundario. De modo tria elemental, la representación gráfica abandona los procedimientos altamente evolucionados y regresa a los sencillos métodos lineanew direction in architecture. This is Kaufmann's task: he establishes a relation between the systems and the forms that represent them using Ledoux's ideas, and thus, he describes the process resulting in the chaotic evolution of Ledoux's works. The architectural system is Kaufmann's definitive tool of analysis. According to Vidler, "it is clear that Kauf-mann intends us to see his "architectural system" as commensurate with intellectual developments, as the manifestation, in other words, of the architect's thought processes" (Vidler 2008: 50).

The arguments above are related to Kaufmann's first objective: "a summarized presentation of the artist's work". Now, it is time to reflect on the second objective, his interpretation of the architectural evolution during the nineteenth and twentieth centuries. Kaufmann briefly mentions Walter Gropius' Bauhaus-Bücher, cubism, Art Nouveau, Secession and Richard Neutra's words in the last chapter entitled "Architec-tural autonomy". However, it is important to understand not only the direct links between Ledoux's body of work les. El grabado en acero y la xilografia desplazan al dibujo al carbón
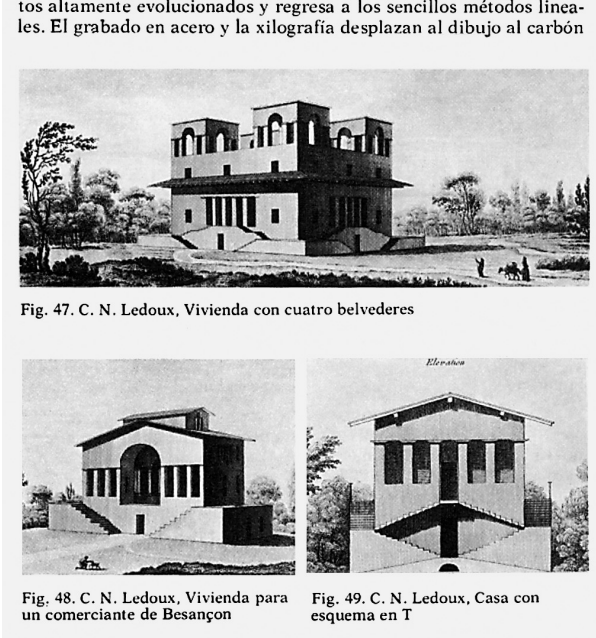

tan floreciente durante el Barroco. $¿$ Qué sentido podía tener en la nueva época esta técnica de suaves degradados, de total integración de los objetos en el ambiente que los rodea, de imitación enganiosa

Algunas realizaciones de Ledoux pueden aclarar el origen de la planta autónoma. El sencillo clasicismo de su apariencia apenas proyctos. En la casa Mézières en Eaubonne el comedor aparece ya 
and the time of Le Corbusier, but also the complete line that Kaufmann draws from one to the other across the nineteenth century. According to Kaufmann, "Ledoux is the first to initiate the long path which connects the Baroque to the architecture of the twentieth century" (1982: 22) and "our own time, similar to Ledoux's, is occupied with similar experiments which, despite their architectural impracticability, are significant due to the tireless ambition of new forms" (1982: 54).

Once architectural autonomy has been established as the main characteristic of both Ledoux's work and modern architecture, the question is: how did it survive during the nineteenth century? Once again, Kaufmann describes a process, but this time not as thoroughly as before, surprisingly, as this was one of the two aims of his research:

"Ledoux's work, which culminated in a vigorous protest against the ClassicalBaroque tradition, had little in common with his neoclassical contemporaries in his last period. His definitive correspondence with twentieth century architectural forms causes profound astonishment. The question it raises is whether this similarity with the architectural style of our time is only superficial and fortuitous or whether there exists a constant development from Ledoux, as the most representative figure of French revolutionary architecture, to our day". (1982: 77-78)

Kaufmann uses the concept of autonomy to reflect on this development throughout the nineteenth century. According to him, the principle of autonomy "preserves its efficacy during the first subsequent decades after the Revolution" which he discusses thoroughly; "weakened as time passed by until it was almost forgotten at the end of the nineteenth century" (1982: 78). If Ledoux's work is sufficient in itself to discuss architecture around 1800 according to Kaufmann, the figure of Le Corbusier -his work is not really analyzed- is sufficient to characterize architecture at the beginning of the twentieth century. The author considers that he has proven the survival of the principle of autonomy during the nineteenth century despite his limited analysis. He considers unquestionable that autonomy reigned in modern architecture. Despite the fact that Kaufmann neither mentions nor discusses a single building by Le Corbusier, "his work was the full affirmation of the new principles" (1982: 93).

\section{From Historiography to Kaufmann}

Von Ledoux bis Le Corbusier has not yet been translated into English. Thus, the ideas Kaufmann presented in this book were made available to the English-speaking public first by Panayotis Tournikiotis in 1999 and, more recently, by Anthony Vidler in 2008. While it is true that his next two books and a series of essays in the Journal of the Society of Architectural Historians were written in English, it is difficult to find the reason why the book was not translated into this language. At this point, and before considering Tournikiotis' and Vidler's analysis, it may be interesting to discuss, at least briefly, the book's editorial life. Von Ledoux bis Le Corbusier was first translated into Italian in 1973 (Milan: Mazzotta); the second edition appeared in 1975. During the next decade, two more translations were published: first, the French version in 1981 (Paris: L'Esquerre) with a second edition in 1990; and second, the Spanish version in 1982 (Barcelona: Gustavo Gili) with a second edition, too, in 1985. Precisely in 1985 appeared the reprint, or unveränderter Nachdruck, in German (Stuttgart: G. Hatje). The interest on this book, at least during the 1980s, cannot be denied. Moreover, in 1992 Von Ledoux bis Le Corbusier was translated into Japanese and in 2002 a new French edition has been published. The question it raises is why the book has never been translated into English. It is an interesting question with a difficult answer which may be the object of another investigation.

In his chapter on art historians, Tournikiotis does not mention the reasons to include Kaufmann in his study; he does not justify his choice. Whereas The Historiography of Modern Architecture is considered a key study, some arguments are forced and hard to agree with.

"It is true, of course, that Kaufmann establishes the foundations of the modern movement without actually describing; his book functions as a manifesto, but it would not be useful as a guide to the architect. (...) In both cases [Pevsner and Kaufmann], however, the text contains a potential architectural project, a 'building' that some architect might one day construct-whether his name is Gropius or Le Corbusier or anything else. It is this specific parameter that determines the operative nature of their discourse". (Tournikiotis 1999: 22-23)

Is it possible to establish something without even describing it? Is Kaufmann's 


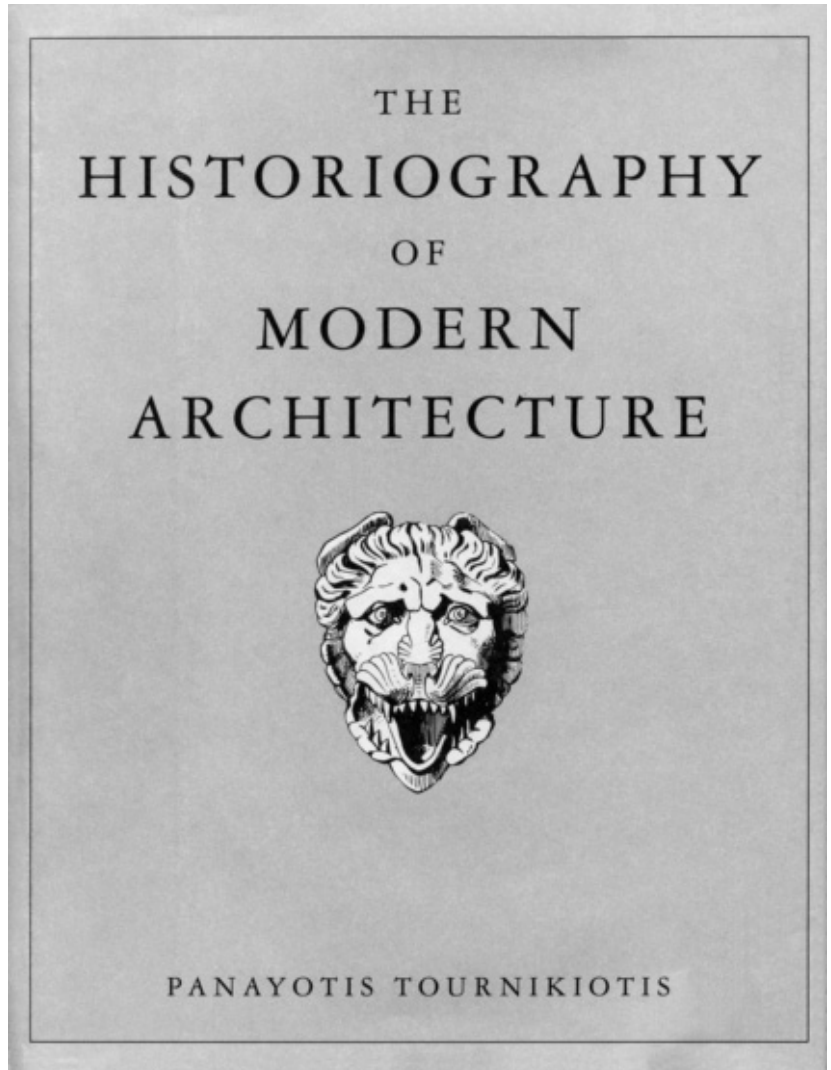

Panayotis Tournikiotis' The Historiography of Modern Architecture, 1999.
Teorie e storia dell'architettura published in 1968. He blames Pevsner and Giedion for being "happy to produce a short-lived, consumable (even rapidly consumable) literature" (1980: 154). According to Tafuri, they are works so present-centered that one finds more opinion than analytical rigor. Moreover, he considers Kaufmann an example of "Illuminist criticism", together with Max Dvořák, member of the Wiener Schule der Kunstgeschich-te. Illuminist criticism introduced an "ambiguity" that is shared by operative criticism. In Tafuri's opinion, it can be considered that Kaufmann's restless study of the architecture in the Age of Reason reveals attitudes which give "new courage" to modern architecture, without fully committing to it. The only artistic revolution which interest this historian is, according to Tafuri, the one initiated by Ledoux around 1800.

It is also hard to agree with Tournikiotis when he refers to the book's structure. According to the thorough examination presented in this essay, this structure would be: a presentation of Ledoux and his work classified in the above mentioned stages (Baroque's unity, revolutionary architecture and the different tendencies until reaching the autonomous solution) and the reinterpretation of autonomous architecture during the nineteenth century and the beginning of the twentieth century. This structure has little in common with the one described by Tournikiotis, maybe because of his choice to describe it together with Pevsner's Pioneers.

"There are structural similarities between the two books. Both begin by noting the existence of what we might schematically call an architecture A, which is a faithful reflection of its age, is described in negative terms, and is dealt with as an abstract entity: only a very few of its representatives are named. Both authors then discern a rift, which takes individual form in the work of the first pioneer to call architecture A into question at a given point in time. They then narrate the lengthy transition to architecture B, during which the pioneers implement their model projects. Architecture B, too, is a faithful reflection of its age; it is described in positive terms and summarized in the work of one architect". (1999: 27)

Ledoux embodies the rupture, according to Kaufmann, but the process described by the author lasts thirty years, not two centuries. Tournikiotis' assertion also contradicts one of Kaufmann's main ideas:
In order to consider Kaufmann's work under the light of the operative criticism it is necessary to turn to Manfredo Tafuri's 
Anthony Vidler's Histories of the Immediate Present: Inventing architectural modernism, 2008 (Tournikiotis [2014])
Ledoux transformed heteronomous architecture, but by studying, using and combining it in the search for something new.

"In both cases, we can recognize the same polemical structure: in order to constitute architecture B as modern and fundamentally new, the authors attempt the exemplary projection of its opposite, architecture A". (1999: 32)

In Kaufmann's case architecture B is the autonomous solution detected in Ledoux's last works, and the transition from one architecture to the other is the evolution within the artist's work. Indeed, this proves the scarce link between the structure described by Tournikiotis and Von Ledoux bis Le Corbusier's content.

Moving on from 1999 to 2008, from Tournikiotis to Anthony Vidler, there are also ideas that are hard to agree with. In this case, a briefer commentary can clarify the claim. "The real subject of the treatise would then be the architecture of Loos, Gropius, Richard Neutra, and Le Corbusier -the architecture of modernism developed between 1900 and 1929" (2008: 37). Is Le Corbusier and modern architecture the real subject of the book? There is no way, after reading the content's analysis presented above, that we can affirm anything other than the real subject of Von Ledoux bis Le Corbusier is Ledoux. Vidler, too, considers this history as a "modern project", whereas we understand it as a "first draft" of a history of architecture in the Age of Reason. Neither Tournikiotis nor Vidler criticizes the lack of detail in Kaufmann's description of the survival process of the principle of autonomy.

These two historiographies are the main sources for English-speaking readers and it has been proven that they should be read, at least, with caution. It is important to take into account that both historiographies consider Kaufmann's together with other historians' discourses, which can lead to misinterpretations. The need for a plain presentation of the content of Von Ledoux bis Le Corbusier has been proven, too, while we wait for the English translation.

\section{From "the History of Art" to "the History of Modern Architecture"}

Some interesting ideas are revealed as a result of rethinking and reinterpreting the content of Von Ledoux bis Le Corbusier, which will help to clarify Kaufmann's contribution to the historiography of modern

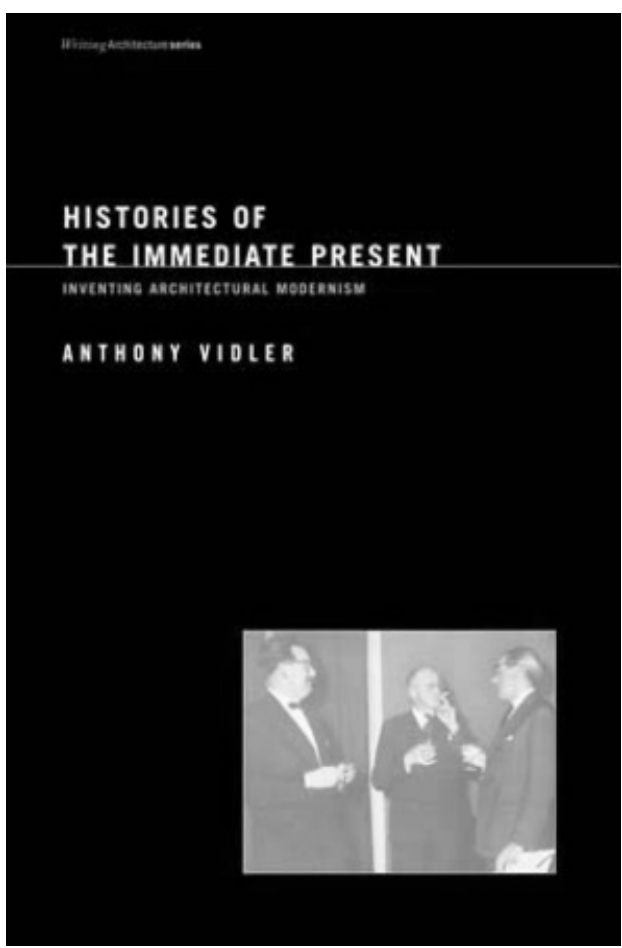

architecture. First, his clear preference for Ledoux and the architecture of the Age of Reason allows us to reconsider Kaufmann as a historian of modern architecture. More-over, at the end of Von Ledoux bis Le Corbu-sier, Kaufmann claims that "to perform an interpretation of current architecture's essence cannot be the object of an historical research work" (1982: 94). It can be inferred that he thought it necessary not only to wait some time, but also to truly understand architecture around 1800 as a first step towards the study of modern architecture.

Second, this study intends to recognize the worth of Kaufmann's task in reevaluating pre- and post-revolutionary architecture, an architecture neglected and forgotten by previous historians. Baroque had been defined as a decadent time until Alois Riegl rejected this consideration in his reevaluation of Spätromische architecture. Sigfried Giedion or Heinrich Wölfflin continued the work and shed some more light on the Baroque. In Kaufmann's words "is the biographer who ventures in an unmapped territory the one that should be praised; someone who discovers an artist or who offers a new image of a personality or an era", like himself (1946: 284). In La estructura histórica del entorno, Marina Waisman defines the exploratory function, "which focuses on aspects misinterpreted by architectural practice or thinking", as one of the functions of the history of architecture (1985: 8). Thus, the contemporary view of works by Ledoux, Boullee and the 
architecture in the Age of Reason that Kaufmann offers has become a way to understand modernity, in a wider sense than just the Modern Movement or modern architecture.

Third, it is important to understand that Kaufmann's evaluation takes place in a time of searching. On the one hand, the search for a new science of art between the 1920s and the 1930s; and on the other hand, the search for a new history of architecture later on in the 1940s. In this context, Kaufmann's reinterpretation of the revolutionary architecture and its connection to rationalist modern architecture opens new paths for the discipline. To understand that the genealogy of modern architecture starts with Ledoux around 1800 is not exclusively Kaufmann's idea. Other theorists like Henry-Russell Hitchcock understood the continuity in architecture from 1800 to the twentieth century. Moreover, some of the subsequent historians of modern architecture have initiated their discourses at the end of the eighteenth century.

To sum up, it can be concluded that Kaufmann himself is a transitional figure between a previous generation of art historians who established fundamental concepts and principles; and others of his own generation who embarked on the hard task of considering modern architecture as a subject of historical research. From the former, Kaufmann inherited an idea of truly methodological research, which he -without architectural education- was able to adapt to the study of architecture around 1800. His work helped the latter as an example, and they applied similar strategies in their investigations, which in fact deal with modern architecture.

Using similar terms as those Kaufmann uses to refer to Ledoux, he could be considered as a limit historian who knows the research methods used on both sides of a river. $\mathrm{He}$ is the one to cross from one side to the other, from the historiography of art to the historiography of modern architecture. He belongs to neither of them, and to both at the same time.

\section{Bibliografia}

Coolidge, John. 1943. Preliminary steps towards "The New History of Architecture". Journal of the Society of Architectural Historians, vol III, nº3: 311.

Erouart, Gilbert. 1980. Situación de Emil Kaufmann. Introduction to Tres arquitectos revolucionarios: Boullée, Ledoux y Lequeu. Barcelona: Gustavo Gili, 7-14. Translated by Xabier Blanquer, Marc Cuixart, Enric Granell and Ricardo Guasch.
Original edition: 1978. Situation d'Emil Kaufmann. Trois architectes révolutionnaires: Boullée Ledoux, Lequeu. Paris : Éditions de la SADG.

Frankl, Paul. 1981. Principios fundamentales de la Historia de la Arquitectura: el desarrollo de la arquitectura europea desde 1420-1900. Barcelona: Gustavo Gili. Translated by Herminia Dauer. Original edition: 1914. Die Entwicklungsphasen der neueren Baukunst. Leipzig: B.G. Teuber.

Hartoonian, Gevork. 2011. The Mental Life of the Architectural Historian: re-opening the Early Historiography of Modern Architecture. Newcastle upon Tyne: Cambridge Scholars Publishing.

Hernández Pezzi, Emilia. 1988. Historiografia de la arquitectura moderna. Madrid: Editorial de la Universidad Complutense.

Kaufmann, Emil. 1982. De Ledoux a Le Corbusier. Origen y desarrollo de la arquitectura autónoma. Barcelona: Gustavo Gili. Translated by Reinald Bernet. Original edition: 1933. Von Ledoux bis Le Corbusier. Ursprung und Entwicklung der autonomen Architektur. Vienna: Rolf Passer.

Kaufmann, Emil. 1943. Claude-Nicolas Ledoux, Inaugurator of a New Architectural System. Journal of the Society of Architectural Historians, III, $\mathrm{n}^{\circ} 3$ : $12-21$.

Kaufmann, Emil. 1946. Nils G. Wollin: 'Desprez en Suède'. Art Bulletin, vol. XXVIII: 283-284.

Panosky, Erwin. 1970. Tres decenios de Historia del Arte en Estados Unidos: impresiones de un europeo transplantado. In El significado de las artes visuales. Buenos Aires: Infinito. Original edition: 1953. "Three decades of Art History in the United States: Impressions of a transplanted European". College Art Journal 14: 7-27.

Scalvini, Maria Luisa and Sandri, Maria Grazia. 1984. L'immagine storiografica dell'architettura contemporanea da Platz a Giedion. Roma: Officina Edizioni.

Schapiro, Meyer. 1936. The New Viennese School. Art Bulletin XVIII, $\mathrm{n}^{\circ} 2$ : 258-266. In: Wood, Christopher S. (ed.), 2003. The Vienna School Reader: Politics and Art Historical Method in the 1930s. New York: Zone Books. 453-485.

Schlosser, Julius von. 2009. The Vienna School of the History of Art- review of a century of Austrian scholarship in German. Journal of Art Historiography, $\mathrm{n}^{\circ} 1$. Translated and edited by Karl Johns. Original edition: 1934. Die wiener Schule der Kunstgeschichte. Mitteilungen des österreichischen Institut für Geschichtsforschungen Ergänzungs-Band 13, Heft $2: 145-228$.

Tafuri, Manfredo. 1980. Theories and History of Architecture. London: Granada Publishing Limited. Translated by Giorgio Verrechia. Original edition: 1968. Teorie e storia dell'architettura. Rome and Bari: Laterza.

Teyssot, Georges. 1980. Clasicismo, Neoclasicismo y "Arquitectura revolucionaria". Introduction to Tres arquitectos revolucionarios: Boullée, Ledoux y Lequeu. Barcelona: Gustavo Gili. 15-35. Trans-lated by Xabier Blanquer, Marc Cuixart, Enric Granell and Ricardo Guasch. Original edition: 1978. Trois architectes révolutionnaires: Boullée, Ledoux, Lequeu. Paris : Éditions de la SADG.

Teyssot, Georges. 1981. Neoclassic and "Autonomous" Architecture: the Formalism of Emil Kaufmann. In: Pophyrios, Demetri (ed.), On the Methodology of Architectural History. Architectural Design, 6/7: 25-33.

Tournikiotis, Panayotis. 1999. The Historiography of Modern Architecture. Cambridge, Massachusetts: The MIT Press. Spanish edition 2014. La historiografia de la arquitectura moder na. Barcelona: Reverté. Translated by Jorge Sainz.

Vidler, Anthony, 2008. Histories of the Immediate Present: Inventing architectural modernism. Cambridge: MIT Press. Spanish edition: 2011. 
Historias del presente inmediato: la invención del Movimiento Moderno. Barcelona: Gustavo Gili. Translated by Moisés Puente.

Waisman, Marina. 1985. La estructura histórica del entorno. Buenos Aires: Nueva Visión.

Wölfflin, Heinrich. 1924. Conceptos fundamentales en la Historia del Arte. Madrid: Espasa Calpe. Translated by J. Moreno Villa. Original edition: 1915. Kunstgeschichtliche Grundbegriffe. Das Problem der Stilentwicklung in der neueren Kunst. Basilea-Munich.

Zucker, Paul. 1951. The Paradox of Architectural Theories at the beginning of the Modern Movement. Journal of the Society of Architectural Historians vol. X, $\mathrm{n}^{\circ} 3$ : 8-14. 